\title{
LABORATORY STUDY AND CLINICAL TRIALS WITH PROLANEST (LONG-ACTING PRILOCAINE) *
}

\author{
Bernard Paradis, M.d., and George Camougis, Ph.D. $\nmid$
}

\begin{abstract}
ANAESTHESIOLOGISTS AND PHARMACOLOGISTS have for many years been searching for an ideal local anaesthetic solution with prolonged action and low toxicity. Until now the only satisfactory way of prolonging the action of a local anaesthetic agent has been the addition of a vascoconstrictor such as epinephrine to the solutions. In spite of its inconvenience, this method is still in use. Oily solutions and anaesthetic suspensions have now been discarded because of the accidents which have occurred with them.
\end{abstract}

\section{ObJectives OF THE STUdy}

The basic objectives of the present study were: (1) to find a substance which could prolong the period of anaesthesia to a degree at least equivalent to the prolongation achieved with epinephrine; (2) to prepare an oil-free solution with sufficient viscosity to permit slow absorption, one which was devoid of toxicity and tissue irritation and would conserve a reversible effect, would prolong analgesia, and would make possible the safe use of high concentrations.

These objectives appeared to us mandatory following our experiences with the use of the classical aqueous solutions which, in our hands, could sometimes produce unforeseen systemic reactions secondary to rapid absorption or intravascular injection.

Following the work of Pellerat and associates in France, ${ }^{1}$ of Smirnov and Starlinger ${ }^{2}$ in Russia, and of Paton ${ }^{3}$ and Loder ${ }^{4}$ in England in 1965, we began a clinical study of the use of mepivacaine (Carbocaine) in Subtosan. A year later we replaced mepivacaine with prilocaine (Citanest $\left.{ }^{(}\right)$) because of its high anaesthetic potency, its low toxicity, its prolonged action, and its high miscibility. At the same time pure polyvinylpirrolidone (Plasdone C) replaced Subtosan.

Many combinations of prilocaine-Plasdone $\mathrm{C}$ were tested, out of which eight different solutions remained of interest. The project was called the CPC (Citanest Polymeric Combination) project, and the compounds were called Prolanest, this being a general term used to indicate a prolonged anaesthetic compound.

Plasdone $\mathrm{C}$ is a stable hygroscopic powder with a molecular weight in the range of 20,000 to 80,000 (average 40,000 ), corresponding to a chain of 192 to 720 monomes units. With its capacity for binding water and absorbing physiological and non-physiological products, Plasdone $\mathrm{C}$ shows a resemblance to the proteins

"Presented at the annual meeting of the Canadian Anaesthetists' Society, Montreal, June 1967.

fDr. Paradis is in the Department of Anaesthesia, Hôpital Ste-Foy, Quebec. Dr. Camougis is with the Laboratory of Biological Research, ASTRA Pharmaceutical Products Inc., Worcester, Massachusetts. 
of normal plasma. Although the structural formula indicates that it should be an undissociated, neutral product, the aqueous solution is slightly acid, with a $\mathrm{pH}$ of 4 , but with no buffering action. A slight migration of one fraction of polyvinylpirrolidone to the anode is observed in electrophoretic experiments (thus negative ions, i.e. a slightly negative charge).

Plasdone $\mathrm{C}$ is a typical colloid of tremendous surface area with possibilities to adsorb other molecules. Strong Plasdone solutions have, of course, a high viscosity and a high $\mathrm{pK}$ (viscosity coefficient), according to the Fiken Tascher formula.

Chemists have suggested that the mixing of prilocaine with Plasdone could fold the hydrocarbon chain, or that there might be a coil of hydrocarbons with pyrrolidone rings projecting in all directions. Crosslinking is a possibility, and the $\mathrm{CO}_{2}$ groups may be engaged for coupling. The binding equilibrium and the interaction forces have been analysed.

After exhausting chemical analyses, it has been impossible to conclude that we have achieved a new pharmaceutical entity. Analyses do not reveal complexing between Plasdone $\mathrm{C}$ and prilocaine. It does not seem that prilocaine is tightly bound to the polymer, because if it were, the $\mathrm{LD}_{50}$ values would have been higher ( Table I).

TABLE I

Toxicity Data: LD $_{50}$ Values for Mice

\begin{tabular}{lll}
\hline & \multicolumn{2}{c}{$\mathrm{LD}_{50}(\mathrm{mg} . / \mathrm{kg} .)^{*}$} \\
\cline { 2 - 3 } Compound & I.P. & I.V. \\
\hline CPC 241 & 220 & $30-35$ \\
Prilocaine & 200 & 33 \\
CPC 251 & 250 & $24-29$ \\
Prilocaine & & 30 \\
\hline
\end{tabular}

*The L.D 60 values are for prilocaine and the prilocaine contained in the CPC solutions.

\section{Objectives and Results of the Laboratory Experiments}

The laboratory experiments were done with the eight solutions (Table II), with particular attention to solutions CPC 241, CPC 251, and CPC 261. The objectives of the research were to determine irritability, toxicity, duration of

TABLE II

VARIETY OF SOLUTIONS USED

\begin{tabular}{cccc}
\hline \hline $\begin{array}{c}\mathrm{CPC} \\
\text { solution }\end{array}$ & $\begin{array}{c}\text { Prilocaine } \\
(\%)\end{array}$ & $\begin{array}{c}\text { Plasdone C } \\
(\%)\end{array}$ & $\mathrm{CO}_{2}$ \\
\hline 61 & 3 & 3.5 & - \\
151 & 3 & 10 & - \\
161 & 3 & 15 & - \\
241 & 4 & 8 & - \\
251 & 6 & 8 & - \\
261 & 8 & 8 & + \\
291 & 2 & 8 & + \\
301 & 3 & 8 & \\
\hline
\end{tabular}


action, and reversibility of the compounds. The investigation consisted of the effect of the different mixtures on: (1) isolated nerve and corneal block; (2) rat sciatic nerve block; (3) peridural anaesthesia in the cat. Histological sections were evaluated for nerve damage.

It may be seen that: (1) The duration of action is manifest on the rat sciatic nerve block (Tables III and IV). There is no manifest prolongation of action on the isolated nerve and with peridural anaesthesia in the cat. (2) The Plasdoneprilocaine combination appears to be non-toxic and non-irritant in that the amount of necrosis seems to be minimal. (3) All solutions are reversible. (4) The solutions are no more toxic to the tissues than free prilocaine in any concentration. (5) Paradoxically, the addition of epinephrine shortens the duration of action instead of prolonging it.

TABLE III

Data on SCIatic Blocks in Rats

\begin{tabular}{|c|c|c|c|c|}
\hline Test solution & $\begin{array}{l}\text { Onset time } \\
\text { in min. } \\
\text { (MT and } \mathrm{H} \text { ) }\end{array}$ & $\begin{array}{c}\text { Dur } \\
\text { in } \\
\mathrm{MT}\end{array}$ & & $\begin{array}{l}\text { Frequency of } \\
\text { complete block } \\
\text { (MT and H) }\end{array}$ \\
\hline CPC 241 & 3 & 138 & 123 & $12 / 12$ \\
\hline Prilacaine $4 \%$ & 3 & 105 & 97 & $12 / 12$ \\
\hline CPC $241(50-50)^{*}$ & 3 & 75 & 81 & $12 / 12$ \\
\hline Prilocaine $2 \%$ & 3 & 76 & 83 & $12 / 12$ \\
\hline CPC 251 & 2 & 122 & 124 & $1.2 / 12$ \\
\hline Prilocaine $5.78 \%$ & 2 & 113 & 133 & $1.2 / 12$ \\
\hline
\end{tabular}

TABLE IV

Data on Sciatic BLOCKS In Rats

\begin{tabular}{lccccc}
\hline \hline $\begin{array}{c}\text { Test } \\
\text { solution }\end{array}$ & $\mathrm{pH}$ & $\begin{array}{c}\text { Onset time } \\
\text { in min. } \\
\text { (MT and H) }\end{array}$ & \multicolumn{2}{c}{$\begin{array}{c}\text { Duration } \\
\text { in min. }\end{array}$} & \multicolumn{2}{c}{$\begin{array}{c}\text { Frequency of } \\
\text { complete block } \\
\text { (MT and H) }\end{array}$} \\
\hline CPC 261 & 6.7 & 2 & 298 & 208 & $12 / 12$ \\
Prilocaine 7.7\% & 6.7 & 1 & 238 & 181 & $12 / 12$ \\
\hline
\end{tabular}

Prilocaine solution in $0.6 \%$ saline. 
TABLE V

Data on Corneal Blocks in Rabitss

\begin{tabular}{lccc}
\hline Test solution & $\begin{array}{c}\text { Onset time } \\
\text { in min. }\end{array}$ & $\begin{array}{c}\text { Duration } \\
\text { in min. }\end{array}$ & $\begin{array}{c}\text { Frequency } \\
\text { of block }\end{array}$ \\
\hline CPC 241 & 2 & 32 & $4 / 4$ \\
Prilocaine 4\% & 2 & 30 & $4 / 4$ \\
CPC 251 & 1 & 36 & $4 / 4$ \\
Prilocaine $5.78 \%$ & 1 & 33 & $4 / 4$ \\
\hline
\end{tabular}

TABLE VI

Intradermal Wheals in Guinea Pigs

\begin{tabular}{lccc}
\hline \hline Test solution & $\begin{array}{c}\text { Onset time } \\
\text { in min. }\end{array}$ & $\begin{array}{c}\text { Duration } \\
\text { in min. }\end{array}$ & $\begin{array}{c}\text { Frequency } \\
\text { of block }\end{array}$ \\
\hline CPC 241 & 2 & 160 & $18 / 18$ \\
Prilocaine 4\% & 3 & 168 & $18 / 18$ \\
CPC 251 & 2 & 179 & $12 / 12$ \\
Prilocaine 5.78\% & 2 & 228 & $12 / 12$ \\
\hline
\end{tabular}

\section{Clinical Study}

Following experiments on isolated nerve, on rat sciatic nerve, on the cornea, and on intradermal wheals in guinea pigs (see Tables V and VI), having obtained from the research laboratory sufficient proof that the mixtures are not injurious to tissue, we proceeded with clinical evaluation. We first began using the mixtures in peripheral nerve blocks, and later we used them for surgical procedures. Four hundred and forty-eight infiltrations were given to one hundred and seventy patients for therapeutic nerve blocks. Seventy-five other patients were given epidural caudal anaesthesia and brachial plexus analgesia for various surgical procedures.

The surgical patients fall into two categories; first the young and healthy persons from the armed forces, their ages ranging from seventeen to thirty years; second, patients of ripe age ranging from thirty to eighty-five years of age. Individual records were kept for each infiltration, including progressive clinical notes concerning the progress of the patient. For surgical patients, careful records were kept of the exact volume administered and of the concentration of the solutions used. The onset and the spread of anaesthesia were noted, but special attention was paid to the duration of action and the recovery time, charted in 
terms of movement and sensation. Notes were also kept with regard to the prolongation of the postoperative analgesic effect, which in many instances eliminated the use of narcotics.

Eight different combinations of solutions were used for either therapeutic nerve blocks or surgical anaesthesia. Early in our investigation, 3 per cent prilocaine was used in 3.5 per cent, 10 per cent, and 15 per cent Plasdone $C$ for therapeutic nerve blocks. Later, 4, 6, and 8 per cent prilocaine solutions were used in 8 per cent Plasdone C. For surgical anaesthesia, 3 and 4 per cent prilocaine in 3.5 and 8 per cent Plasdone $C$ were used. After a few months carbonated solutions were evaluated. Epinephrine was never used in the study.

A special study was made regarding the formation of methaemoglobin. Fifty samples from ten patients were taken and analysed two, four, six, eight, and twelve hours following the administration of Prolanest, where a minimum of $600 \mathrm{mg}$. and a maximum of $1200 \mathrm{mg}$. of prilocaine-Plasdone had been injected. One patient received as much as $1100 \mathrm{mg}$. per day for seven days.

\section{Results with TherapeUtic Nerve Blocks}

For therapeutic nerve blocks (Table VII), results classified as excellent correspond to patients who were free of symptoms after the first infiltration and did not necessitate more than two further infiltrations. Results classified as good correspond to those who were partially relieved of their symptoms and who were kept under treatment for many months. Results classified as nil correspond to those who showed no improvement after two or three infiltrations.

TABLE VII

Therapeutic Nerve Blocks: Results for Each Patient*

\begin{tabular}{|c|c|c|c|c|c|c|}
\hline \multirow{2}{*}{$\begin{array}{l}\text { Number } \\
\text { of } \\
\text { patients }\end{array}$} & \multicolumn{2}{|c|}{ Nerve blocks } & \multicolumn{4}{|c|}{ Results } \\
\hline & type & number & excellent & good & average & nil \\
\hline 36 & sympathetic & 88 & & 3 & 31 & 2 \\
\hline 7 & stellate & 18 & & 2 & 5 & \\
\hline 1 & gasserian & 1 & 1 & & & \\
\hline 3 & spheno-palatine & 18 & & 2 & 1 & \\
\hline 49 & supra-scapular & 151 & & & 49 & \\
\hline 23 & $\begin{array}{l}\text { periand intra- } \\
\text { articular without } \\
\text { cortisone }\end{array}$ & 37 & & 4 & 18 & 1 \\
\hline 17 & $\begin{array}{l}\text { peri and intra- } \\
\text { articular with } \\
\text { cortisone }\end{array}$ & 23 & 2 & 12 & 3 & \\
\hline 24 & Para-vertebral & 40 & & 3 & 17 & 4 \\
\hline 10 & Continuous peridural & 72 & & & 10 & \\
\hline 170 & & 448 & $\begin{array}{c}3 \\
(1.7 \%)\end{array}$ & $\begin{array}{c}26 \\
(15.2 \%)\end{array}$ & $\begin{array}{c}134 \\
(78.8 \% 0)\end{array}$ & $\stackrel{7}{(4.1 \%)}$ \\
\hline
\end{tabular}

*These are results obtained in the therapeutic nerve block. Spheno-palatine block: the patient classified average, received twelve infiltrations, one per month during the past year. 


\section{Results with Surgical Procedures}

In surgery, seventy-five patients were operated upon under regional anaesthesia with Prolanest. Table VIII indicates the type of solution used and the regional anaesthesia performed. Tables VIII, IX, and $\mathrm{X}$ give, at a quick glance, a record of the classification of patients by age, the doses of Prolanest used, the onset of action, and the duration of action. Comparative studies were made in Table XI. Table XII gives the comparative evaluation between the type of solution used and the necessity of postoperative sedative, within five hours following the operation.

It has been noted that narcotics were seldom necessary when CPC 241 was used and especially with caudal anaesthesia and brachial block. This appears to be due to the fact that, on one hand, the viscosity of this solution is greater than that of CPC 61 and the usual prilocaine solutions, and, on the other, Plasdone permits the use of higher concentrations of prilocaine (4\%) without endangering the nerve fibre.

TABLE VIII

Surgical Procedures Performed with Different Solutions of Prolanest

\begin{tabular}{lrrrrrr}
\hline & \multicolumn{5}{c}{ Type of solution } & \\
\cline { 2 - 6 } $\begin{array}{l}\text { Cases of } \\
\text { regional }\end{array}$ & CPC & CPC & CPCC & CPCC & Total \\
anaesthesia & 61 & 241 & 291 & 301 & 40 \\
\hline Epidural & 23 & 13 & & 4 & 20 \\
Caudal & 9 & 9 & 1 & 1 & 13 \\
Brachial & 3 & 8 & 1 & 1 & 2 \\
I.V. & 2 & & & & 75 \\
Total & 37 & 30 & 2 & 6 & & \\
\hline
\end{tabular}

TABLE IX

Surgical Procedures: Age, Onset of Action and Dose of Prolanest

\begin{tabular}{cccc}
\hline \multicolumn{2}{c}{$\begin{array}{c}\text { Number of } \\
\text { patients }\end{array}$} & $\begin{array}{c}\text { Onset of action } \\
\text { (min.) }\end{array}$ & $\begin{array}{c}\text { Doses injected } \\
(\mathrm{mg} .)\end{array}$ \\
\hline $\begin{array}{c}\text { Age (range 17-85 years, } \\
\text { mean 42.3 years) } \\
<30 \text { years }\end{array}$ & & \\
$>30$ years & 22 & $2-30$ & $272-1200$ \\
& 53 & average 11.9 & average 528.1 \\
\hline
\end{tabular}


TABLE $\mathrm{X}$

Surgical. Procedures: Duration of ACTION (MIN.)

\begin{tabular}{ll}
\hline \multicolumn{1}{c}{ Motor } & \multicolumn{1}{c}{ Sensory } \\
\hline 80-300 & $150-300$ \\
average 194.1 & average 242.3 \\
\hline
\end{tabular}

TABLE XI

Surgical Procedures: Duration of Sensory Anaesthesia Related to Age

\begin{tabular}{cc}
\hline \hline Age (years) & $\begin{array}{c}\text { Duration of sensory } \\
\text { anaesthesia (min.) }\end{array}$ \\
\hline$<30$ & 230 (3 hours 50 min.) \\
$>30$ & 251 (4 hours 11 min.) \\
\hline
\end{tabular}

TABLE XII

Surgical Procedures: Postoperative Analgesia Time

\begin{tabular}{lcc}
\hline Solutions & $\begin{array}{c}\text { Number of } \\
\text { cases }\end{array}$ & $\begin{array}{c}\text { No sedative necessary } \\
5 \text { hours postoperatively }\end{array}$ \\
\hline CPC 61 & 37 & $31(84.6 \%)$ \\
CPC 241 & 30 & $28(92.8 \%)$ \\
CPCC 291 & 2 & $1(50 \%)$ \\
CPCC 301 & 6 & $5(83.3 \%)$ \\
\hline
\end{tabular}

The side-effects taken into consideration in the study are the usual complications encountered with all regional anaesthesia. They were noted and tabulated during the time of the anaesthetic procedure and up to five hours postoperatively. Table XIII gives an account of the type and the frequency of these side-effects compared with the type of solution used. It is noteworthy that the best results were obtained from solution CPC 241.

TABLE XIII

Surgical Procedures: Side-Effects with the Different Solutions Used

\begin{tabular}{|c|c|c|c|c|c|}
\hline \multirow[b]{3}{*}{ Side-effects } & \multirow{2}{*}{\multicolumn{3}{|c|}{ Solutions of Prolanest used }} & \multicolumn{2}{|c|}{ Total } \\
\hline & & & & \multirow{2}{*}{$\begin{array}{c}\text { number } \\
\text { of } \\
\text { cases }\end{array}$} & \multirow{2}{*}{$\begin{array}{c}\text { per } \\
\text { cent }\end{array}$} \\
\hline & CPC 61 & CPC 241 & CPCC 301 & & \\
\hline Fall in B.P. & 4 & 2 & 1 & 7 & 9.3 \\
\hline Palour & 5 & 2 & & 7 & 9.3 \\
\hline Nausea & 1 & & & 1 & 1.3 \\
\hline Shivering & 1 & & & 1 & 1.3 \\
\hline Cyanosis & & & 1 & 1 & 1.3 \\
\hline Total & $11 / 37$ & $4 / 30$ & $2 / 8$ & 17 & \\
\hline Per cent & 29.9 & 13.3 & 25 & & 22.6 \\
\hline
\end{tabular}




\section{Discussion of Results}

In terms of the objectives of the present study, we have attained positive results consistently, both in the laboratory and in clinical investigation.

The laboratory experiments clearly demonstrated, for all solutions tested: (1) lack of irritability to the tissues; (2) complete reversibility of action; (3) a tolerance at least equal to that obtained with prilocaine in aqueous solution; (4) a prolongation of action with mixture CPC 241 and CPC 251 on the sciatic nerve block.

The clinical investigation showed: (1) that the duration of action is notably superior to that found in laboratory experimentation; (2) that the duration of action of Prolanest is superior to corresponding concentrations of prilocaine with epinephrine; (3) that tolerance by the tissues is strikingly evident; (4) that the action of all solutions, even with as high a concentration as 8 per cent prilocaine in 8 per cent Plasdone, is totally reversible; (5) that the solutions, being isotonic, do not cause dehydration of the nerve tissues; (6) a very beneficial result in surgery, in that Prolanest, especially CPC 24l, prolongs the postoperative analgesic effect; this was particularly noted with brachial blocks and caudal analgesia (it is to be noted that no systemic reactions ever developed, as is so frequently the case with aqueous solutions ); (7) that methaemoglobin does not develop with doses as high as $1200 \mathrm{mg}$. We postulate that the absence of methaemoglobin formation is due to the fact that the absorption of prilocaine is considerably slowed, or that the Plasdone $\mathrm{C}$ possesses a reducing action on methaemoglobin.

\section{Concluston}

Prolanest is a new solution of prilocaine with long action. This solution is well tolerated, non-irritant, totally reversible, and free of side-effects, and it causes no methaemoglobin formation. We believe it is an improvement for therapeutic nerve block, for surgery of the extremities, and for saddle blocks. We have found its use safer with elderly patients, owing to its slow absorption and minimal side-effects.

\section{RÉSUMÉ}

L'addition d'épinéphrine a été et est encore le seul moyen de prolonger l'action d'un anesthésique local. Basé sur les expériences des chercheurs français, allemands, russes et américains, lesquels ont expérimenté, vers les années 1948, l'usage de la procaine diluée dans la polyvinylpirrolidone, nous avons recherché la formation d'un anesthésique à action prolongée, non plus par l'addition d'épinéphrine, mais par l'association de l'agent anesthésique à un solvent qui retarde l'absorption du produit, permet son contact plus prolongé avec le nerf.

Nous avons fait préparer des solutions diverses de polyvinylpirrolidone avec de la prilocaine. Nous avons porté notre attention vers la prilocaine, parce que cet agent anesthésique est le moins toxique et le plus rapide d'action, qu'il a une 
action plus prolongée que celle de tous les autres anesthésiques. Mais la principale raison, est l'extraordinaire facilité avec laquelle la prilocaine se mélange avec la polyvinylpirrolidone. Cette miscibilité a fait penser aux chimistes et aux pharmacologistes, que ce mélange était plus qu'un simple mélange physique, plus qu'une simple solution, que c'était peut-être la réalisation d'un complexe nouveau par "binding".

L'objection principale à l'usage de la prilocaine, c'est la formation de méthémoglobine. Ce point de vue a été tout spécialement étudié durant la recherche faite. Les expériences de laboratoire ont porté sur la réaction du mélange sur les nerfs sciatiques isolés, sur la cornée, au cours des péridurales sur le chat ou à celle de l'irritabilité du nouveau composé, sa toxicité, sa tolérance et sa réversibilité.

L'étude clinique a envisagé d'abord les indications thérapeutiques au cours des infiltrations. Puis cette étude s'est élargie au domaine de la chirurgie, vu les bons résultats obtenus avec les infiltrations.

L'on a prouvé au laboratoire, la sécurité de ce mélange nouveau ou de ce complexe nouveau. En clinique, nous avons étudié le complexe en toute sécurité de toxicité, convaincu que la tolérance de la prilocaine était augmentée et que sa toxicité en était par le fait, diminuée. Les résultats ont prouvé que l'augmentation de la durée était plus longue que celle prévue, spécialement avec une proportion qui a retenu entre autre notre attention, soit la solution CPC 241 , i.e. celle contenant 4 pour cent de prilocaine et 8 pour cent de polyvinyl. Mais le plus évident est la grande tolérance au produit, la faible toxicité, la propriété analgésique post-opératoire et l'absence totale de méthémoglobine.

En pratique, nous ne voudrions pas revenir aux solutions aqueuses, vu le danger très grand de réactions systémiques lors de doses fortes, comme au cours de lanesthésie caudale et du blocage du plexus brachial et des infiltrations du sympathique lombaire.

L'absence de méthémoglobine avec des doses aussi fortes que $1200 \mathrm{mg}$, ajoute du poids à notre préférence de ce complexe sur le même produit, en solution aqueuse.

\section{ACKNOWLEDGMENTS}

Particular thanks are due to our colleague, Dr. R. Brault, who helped us in translating this paper.

\section{REFERENCES}

1. Pellerat, J.; Maral, R.; \& Murat, M. Retardant Subtosan (Subtosanretard) and Its Applications. J. méd. Lyon. 28: 641 (1947).

2. Starlinger, V. Delayed Action Anaesthesia. Zentralbl. Chir. 70: 1728 (1943).

3. PAton, S. L. Treatment of Injuries to the Chest Wall with Long-acting Local Anaesthetic. Brit. J. Clin. Pract. 17: 391 (1963).

4. Loder, R. E. A Local Anaesthetic Solution with Longer Action. 


\section{SELECTED BIBLIOGRAPHY}

Anden, G. P.; Lond, M. B.; Mandow, G. A.; Stoneham, F. J. R.; \& CaMb, M. B. Plasmosan in the Prevention and Treatment of Shock. Windsor Group of Hosp. (1951).

Bahal, C. K. \& Kostenbauder, H. B. Interaction of Preservatives with Macromolecules VBinding of Chlorobutanal, Benzyl Alcohol, and Phenylethyl Alcohol by Nonionic Agents. School of Pharmacy, Temple University, Philadelphia (1963).

Behen, J. J.; DwYer, R. F.; \& BierL, B. A. Determination of Polyvinylpyrrolidone by an Infrared Absorption Method. Research Laboratory, Union Carbide Corporation, Linde Division, Tonawanda, New York (1963).

Blauc, Seymour M. \& Ahsan, Sayed S. Interaction of Scorbic Acid with Nonionic Macromolecules. University of Iowa (1960).

-_- Interaction of Parabens with Nonionic Macromolecules. University of Iowa, College of Pharmacy (1960).

Bonica, J. J. The Management of Pain. Philadelphia: Lea and Febiger (1953), p. 214.

Bonica, J. J.; Backup, P. H.; Anderson, E. E.; Hadfield, D.; Cheprs, W. F.; \& Monk, B. F. Peridural Blocks: Analysis of 3,637 Cases and a Review. Anesthesiology. 18: 723 (1957).

Botre, C.; Crescenzi, V. L.; \& Mele, A. A Study on Micelle Formation in Colloidal Electrolyte Solutions. Laboratorio Ricerche, sulla structura e l'attivita di composti chimici. Roma (1958).

Boufdreaux, J. \& Bourdin, J. S. Delayed Action Local Anesthesia. Méd. français 5 ( 1945).

Bromage, P. R. Exaggerated Spread of Epidural Analgesia in Arteriosclerotic Patients. Brit. M. J. 2 (1962).

-- Physiology and Pharmacology of Epidural Analgesia. Anesthesiology. 28 (1967).

-- Spread of Analgesic Solutions in the Epidural Space and Their Site of Action: A Statistical Study. Brit. J. Anaesth. 34: 161 ( 1962 ).

-_- Vasopressors. Canad. Anaesth. Soc. J. 7: 310 (1961).

Bromage, P. R.; Burfoot, M. F.; Chowell, D. E.; \& Petrigrew, R. T. Quality of Epidural Blockade. I: Influence of Physical Factors. Brit. J. Anaesth. 36: 342 (1964).

Bromage, P. R. \& Burfoot, M. F. Further Studies in the Distribution and Site of Action of Extradural Local Anaesthetic Drugs Using ${ }^{14} \mathrm{C}$ Labelled Lidocaine in Dogs. 3rd Cong. Nund. Anaesth. Tom. 1. Sāo Paulo (1964), p. 371.

-n Quality of Epidural Blockade. II. Influence of Physico-chemical Factors: Hyaluronidase and Potassium. Brit. J. Anaesth. 38: 857 (1966).

-- Quality of Epidural Blockade. III. Carbonated Local Anesthetic Solutions. Brit. J. Anaesth. In press.

Crawford, O. B. The Technique of Continuous Peridural Anesthesia for Thoracic Surgery. Anesthesiology. 14: 316 (1953).

De Dalva, Salvatore Joseph; Migliarese, Somerset; \& Migliarese, Joseph. Anesthetic Preparations Containing Potentiated 4/3 (p-butoxyphenoxy) Propylmorpholine; 3-butyl1-(2-dimethylamino ethoxy) isoquinoline; 2-dimethylamino-2'6'-acetoxylidide. Ser. no. 209281 (July 12, 1962).

De Seze, S.; Ordonneau, P.; \& Deuit, R. Preliminary Remarks on the Use of Novocaine Associated with Concentrated P.V.P. Solutions in Rheumatology. Rev. rhum. 14: 138 (1947).

Dogliotri, A. M. Traitement des syndromes douloureux de la périphérie par l'alcoolisation sub-arachnoidienne des racines postérieures à leur émergence de la moelle épinière. Press Med. 29: 1249 (1931).

Durel, P. The Use of P.V.P. in Concentrated Solution as a Retarding Vehicle. J. des praticiens. 273, 288, 295 (1948).

Durel, P. \& Laroux, P. A New Retarding Vehicle for Drugs. Gaz. méd. de France. 206: 151 (1946).

Durrans, S. F. High Extradural Segmental Block. Anaesthesia. 2: 106 (1947).

Dwyer, R. F. \& Lewandowskr. Determination of Polyvinylpyrrolidone by an Iodine Titration Method. Tonawanda, N.Y. (1963). Anal. Biochem. 9 (1964).

Ekrlom, L. \& Widman, B. A Comparison of the Properties of LAC-43 Prilocaine and Mepivacaine in Extradural Anaesthesia. Acta anaesth. scandinav. (1966).

Eruxsson, E. K. In The Mechanism of Action of Local Anesthetics, edited by P. R. Bromage. Heidelberg: Springer Verlag (1966). 
FIELD, E. J. Observations on the Passage of Weed's Prussian Blue Mixture along the Axis Cylinders and Interfibre Fluid of Nerve. J. Neurol. Neurosurg. Psychiat. 14: 1 (1951).

Frumin, M. J.; Schwartz, H.; Bunns, J. J.; Bhodie, B. B.; \& Papper, E. M. Sites of Sensory Blockade during Segmental Spinal and Segmental Peridural Anesthesia in Man. Anesthesiology. 14: 576 (1953).

Galindo, A. Hepatic Circulation and Hepatic Function during Anaesthesia and Surgery. Canad. Anaesth. Soc. J. 12: 262, 337 (1965).

Hehre, F. W.; Yles, R. B.; \& Hipona, F. A. Continuous Lumbar Peridural Anesthesia in Obstetrics: III. Attempts to Produce Spread of Contrast Media by Acute Vena Cava Obstruction in Dogs. Anesth. \& Analg. 45: 551 (1966).

Hueper, W. C.; Landsberg, J. W.; \& Eskridge, L. C. The Effects of Intravenous and Intraperitoneal Introduction of Polyvinyl Alcohol Solutions upon the Blood. New York: Warner Institute of Therapeutic Research (1940).

Jacques, André \& Hudon, Fernando. Les Substitutes du Sang. Bull. Assn. méd. langue franc. Canad. L'Union Médicale du Canada, Tome 80 (mars 1951), pp. $2-3$.

Lachman, L.; Weinstein, S.; Swartz, C. J.; Urbanyi, T.; \& Cooper, J. Color Stability of Tablet Formulations: III. Comparative Light Fastness of Several Water-soluble Dyes and Their Corresponding Lakes. Research Depart., Ciba Pharm. Prod. Inc. (1960).

Lambling, A. \& Soullard, J. Retarded Anesthesia of the Sphincter Ani in Treatment of Anal Fissures. Arch. mal. appl, dig. 258 (1946).

Lechat, P.; Deleau, D.; \& Griffé, R. A. Influence de l'ion potassium sur l'activié des anesthésiques locaux. Med. exper. (Basel). 11: 157 (1964).

LEger, L. Subtosan as a Retarding Medium in Rachianesthesia. Presse med. 58: 670 (1947).

LoDer, R. E. A Long Acting Local Anesthetic Solution for the Relief of Pain of the Thoracotomy Thorax. 17:375 (1962).

Marx, G. F.; Zemaitis, M. T.; \& ORKIN, L. R. Cerebro-spinal Fluid Pressures during Labor and Obstetrical Anesthesia. Anesthesiology. 22: 348 (1961).

Maurer, Paul H. The Antigenicity of Polyvinyl Pyrrolidone i 1,2. Depart. Pathol. Univ. Pittsburg (1956).

-- The Antigenicity of Polyvinyl Pyrrolidone 11/1,2. Depart. Pathol. Univ. Pittsburg (1957).

Maykut, Madelaine O. Studies on Anaesthetics with Prolonged Action. Canad. Anaesth. Soc. Annual Meeting, Montebello (1953).

Meidinger, F. Relation between the Duration of Local Anesthetics and the Viscosity of the Solvent (Scurocaine with Subtosan as an Absorption Retardant). Soc. Biol. 139: 907 (1945).

Mellstam, Lars. Pharmacological Data and Clinical Reports Concerning the New Longacting Analgesic LAC-43 Marcaine. Acta anaesth. scandinav. (1966).

MrYaWakt, G. M.; Patel, N. K.; \& Kostrmbauder, H. B. Interaction of Preservatives with Macromolecular III Parahydroxy-benzoic Acid Esters in the Presence of Some Hydrophilic Polymers. Vol. XLVIII.

Molyneux, P. \& Frank, H. P. The Interaction of Polyvinylpyrrolidone with Aromatic Compounds in Aqueous Solution: III. A Madel for the Molecular Expansions Caused by Anionic Cosolutes. Institute of Technology, Chicago (1964).

Moonow, W. F. K. Unexplained Spread of Epidural Anesthesia. Brit. J. Anaesth. 31: 359 (1959).

Naranjo, Plutarco \& Banda de Naranjo, Enriqueta. Molecular Weight and Plasma Substituting Effectiveness of 3 Plasma Expanders. Dept. of Pharm., Univ. Central and Research Dept., L.I.F.E. Lab., Quito, Ecuador (1958).

PATEL, N. K. \& Foss, N. E. Interaction of Some Pharmaceuticals with Macrornolecules: I. Effect of Temperature on the Binding of Parabens and Phenols by Polysorbate 80 and Polyethylene Glycol 4000. School of Pharmacy, Duquesne University, Pittsburg (1963).

Pellerat, J.; Maral, R.; \& Myrat, M. Les Applications du subtosanretard. J. méd. Lyon. (1947).

Quevauviller, A. Hypertonic Subtosan Prolongs the Anesthetic Action of I.V. Injected Evipan in the Mouse. Presse Med. 19 (1947).

Ravin, Henbert A.; Seligman, Arnold M.; \& Fine, Jacob. Polyvinyl Pyrrolidone as a Plasma Expander: Studies on Its Excretion, Distribution and Metabolism. Boston. 247: no. 24 (1952).

Rutchie, J. M.; Rutchie, B.; \& Greengand, P. The Active Structure of Local Anesthetics. J. Pharmacol. Exper. Therap. 150: 152 (1965). 
-- The Effect of the Nerve Sheath on the Action of Local Anesthetics. J. Pharmacol. Exper. Therap. 150: 160 (1965).

SiboulEx, A. Use of Subcutaneous Injections of Novocaine-Subtosan in the Treatment of Anal Pruritis. Ann. Dermatol. syphilig. bull. soc. française dermatol. syph. no. 5 (1947).

SoulataAc, A. \& Barbizet, J. Use of Substances Which Retard Diffusion in Intracerebral Injection of Anesthetics. Lab. of Univ. of Paris, Compt, rend. soc. biol. 141 (1947).

Usublaga, J. E.; WikinseI, J.; Wheinsk, R.; Usubiaga, L. E.; \& Pontremoli, M. Transfer of Local Anesthetics to the Subarachnoid Space and Mechanism of Epidural Block. Anesthesiology. 25: 752 (1964).

Wolf, W. F. A Model of Active Carbon. Research Dept., Standard Oil Co., Whiting, Indiana (July, 1958).

Youncman, H. R. Toxic Reactions in Epidural Anesthesia. Anesthesiology. 17: 632 (1956). 